\title{
The reasons for architectural monuments destruction and methods of capacity reinforce for bases and fundaments
}

\author{
Mykola Orlenko \\ Ukrainian special scientific-restoration project-build-production corporation "Ukrrestavratsiya" \\ 6, Boryspilska str., Kyiv, Ukraine, 02099 \\ ukrrestavratsiya@ukr.net, orcid.org/0000-0002-4154-2856
}

The manuscript was received on 22.04.2017 and was accepted after revision for publication on 06.10.2017

DOI: $10.26884 / 1707.1901$

\begin{abstract}
The main problem of monuments' emergency state is poor condition of the bases and foundations often due to their moisture. Uneven foundations subsidence leads to redistribution of efforts in bearing constructions and static instability of the base-foundation-building system. That's why any restoration starts with the removal of their emergency state.

Using the example of Mykola Pritisk's Church on Podil, where groundwater underflooding caused the collapse in the south-eastern part of the building, describes how the restoration works on the monument, which began with the reinforcement of damaged foundations and framework for static recovery of base-foundation-building system, measures to protect foundations and basements from underflooding, ensuring reliable vertical and horizontal waterproofing for the basement walls and floors, and all the underground part of the church, and works for antiseptic treatment of biodamaged and saline walls and plaster surfaces. After that, the organization of reliable geodetic control for the structure deformation was ensured.
\end{abstract}

Keywords: bases and fundaments, groundwater, intensification

\section{INTRODUCTION}

The problems of the alert condition for bases and foundations of buildings are the main problems of monuments restoration. That is why all the work prior the restoration measures require liquidation of alert condition for the bases and foundations [1 -5].

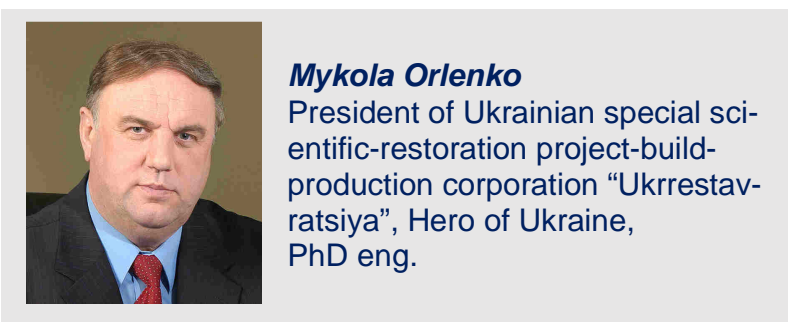

The ways of overcoming these problems should be considered using the example of the church of St. Nicholas the Wonderworker (Mykola Pritisk's Church - architectural monument of XVII - XVIII c. of National importance in Kyiv at the Podil (security Nr.19), where southeastern structures collapsed in May 1983 due to groundwater underflooding of basis and foundations resulting that the car-

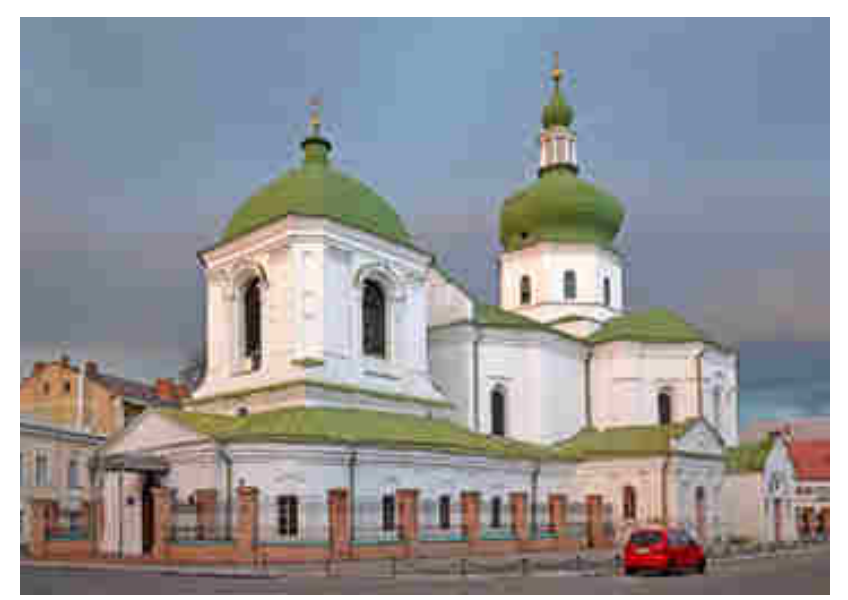

Fig.1. General view of Mykola Pritisk's church 


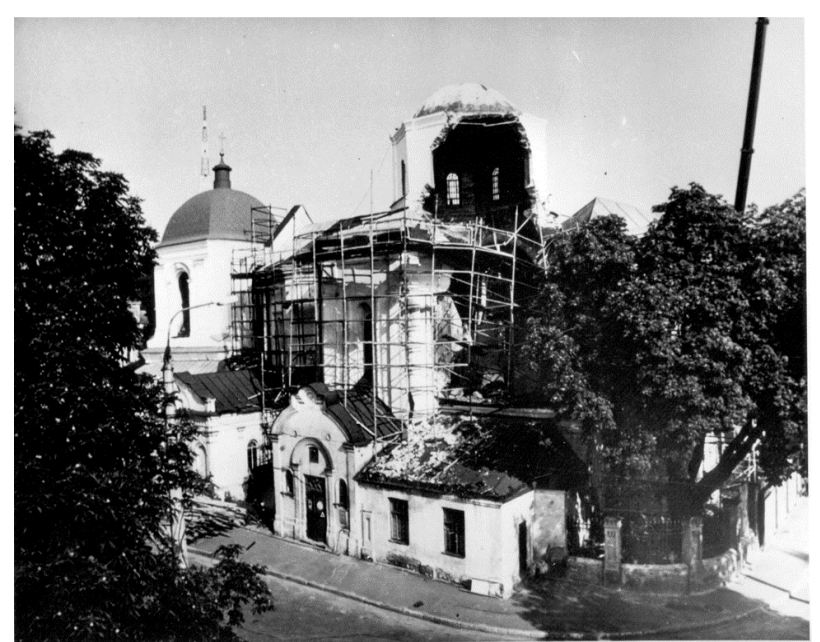

Fig.2. Alert condition of the Mykola Pritisk's church (Photo May 1983)

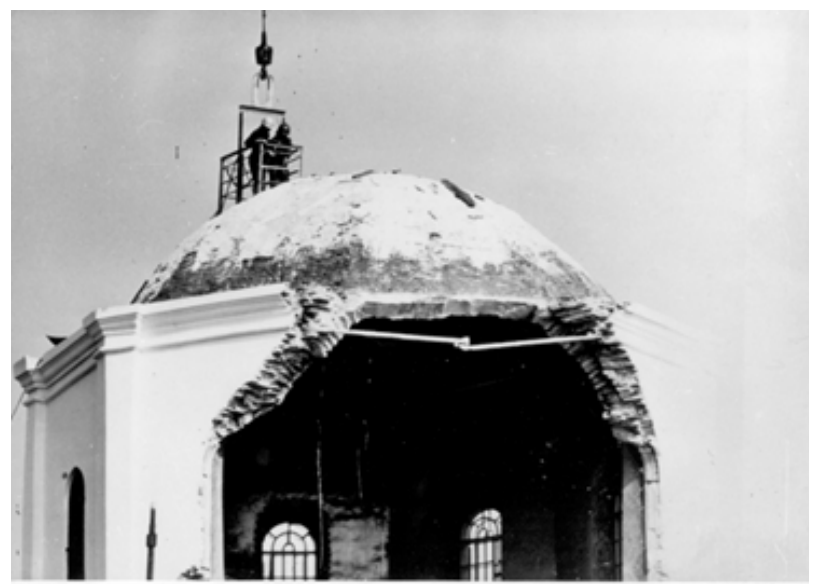

Fig.3. Part of Mykola Pritisk's church octagonal drum

rier pylon and two reinforcing arches, which were based on it, cylindrical vaults and three sides of an octagonal drum were destroyed (Figs.2, 3).

\section{MATERIALS AND METHODS}

The purpose of the article is as follows: to illustrate the consequences of moisturizing bases and foundations using the example of particular architectural monuments, and how these problems are solved by experts of the "Ukrrestavratsiya" corporation. The methods of architectural and comparative analysis were used in the article. The details were provided for the elimination of the alert condition for the foundations and basements moisture by groundwater [6 - 10].

\section{RESULTS AND DISCUSSION}

The main reasons for the alert condition of the monument were raising the level of groundwater in recent years after the construction of the subway at Podil, which was like a dam and blocked the flow from Tarasivska and Zamkova mountains in the Dnieper, uneven subsidence of foundations that caused redistribution for efforts in carrying structures, which destroyed previously established balance in the base-foundation-building system.

Previously, during the centuries of facilities exploitation, the issue of infiltration water derivation, leading to periodic waterlogging of soils of the basis and material of the foundation, was not solved.

Consequently, full or partial degradation of the mortar and bricks appeared.

Given the fact that also, a bus station and market were for many years located near the church, and the traffic of large trucks and buses caused vibrating load on the foundation and basis.

To elucidate and clarify the reasons for the alert condition of the church, Ukrainian main state institute of engineering studies (UkrDIINTD) performed a complex field, laboratory and cameral geological studies technical report in 1983 [11]. In 1984, 9 pits were made in addition to the previous studies to clarify the soil structure of the base and foundation material (Fig.4).

Soil conditions at the construction site are summarized in the Tables 1 and 2.

At a depth of laying the foundation, bearing layers for the base are soils 2, 3 and 5.

The foundation material, as it is seen from the pits, is uniform. In the pits number 1, 4 and 5 , the foundation is made of bricks on limestone mortar. In the pits number 2, 3, 6 and 7, the foundation is made of rubble masonry (slab and granite boulders of $100 \mathrm{~cm}$ ). The sole rubble foundations are located at a depth of 2,4 to 3,55 meters. After the rubble masonry, the brick masonry, which goes to the surface, is made. Sand and brickbat are used as a filler in the masonry. The masonry within the foundation in the pits 5,8 , and 9 has a vertical crack of $2 \mathrm{~cm}$ wide. Sections see Figs. 5 - 8 . 


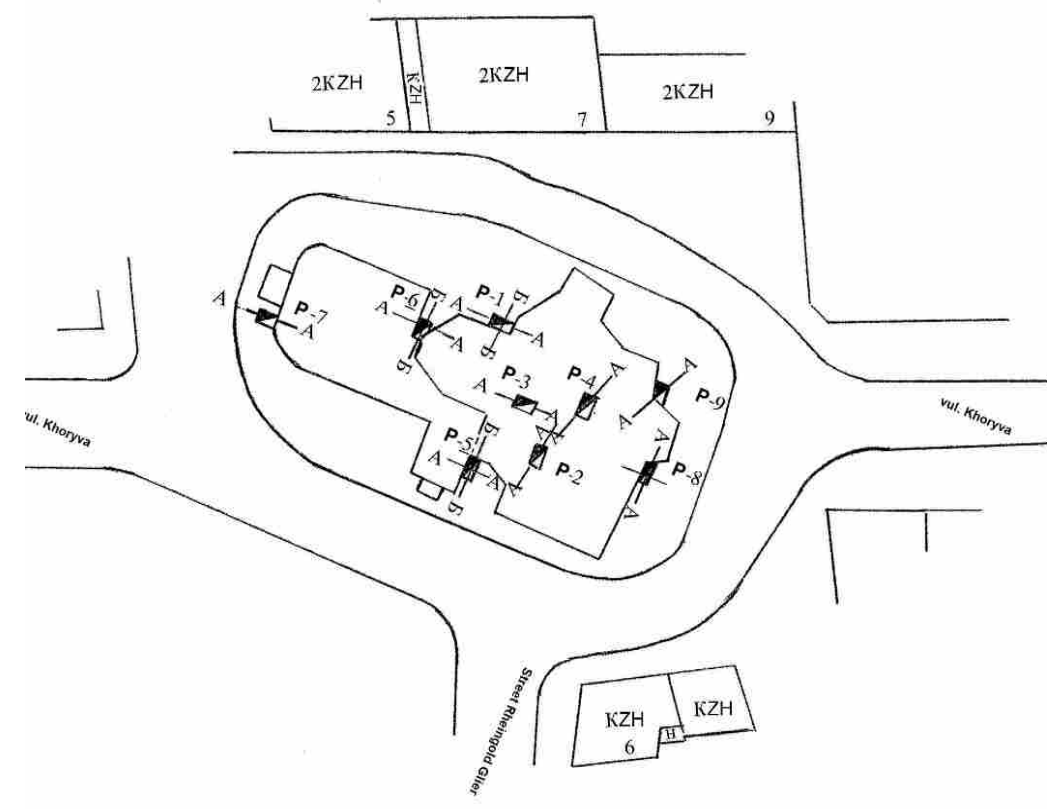

Fig.4. Layout for pits

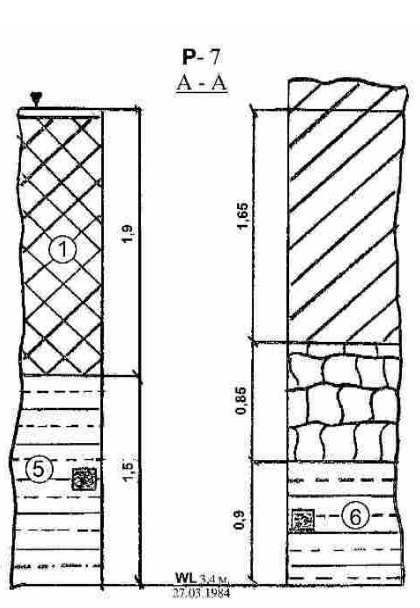

Fig.5. Section for the pits Nr.7

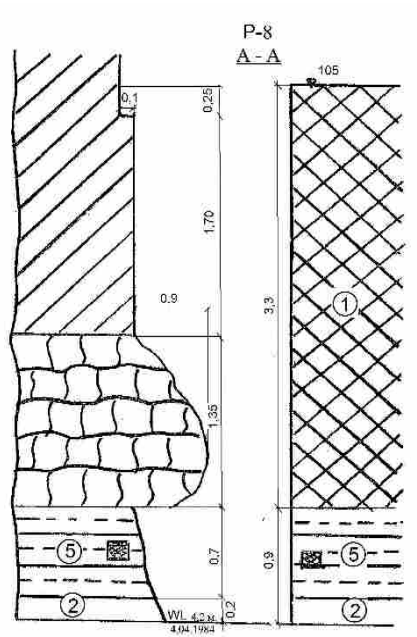

Fig.6. Section for the pits Nr.8

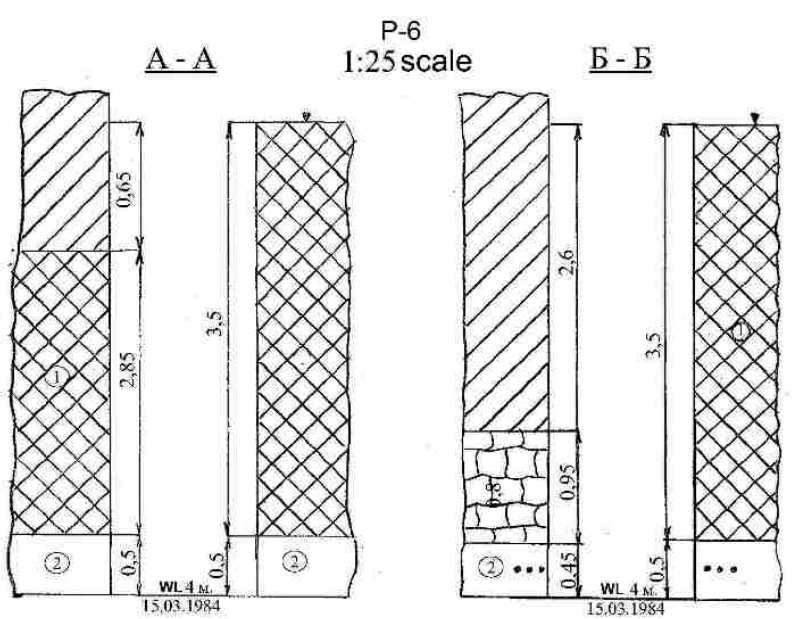

Fig.7. Section for the pits Nr.6

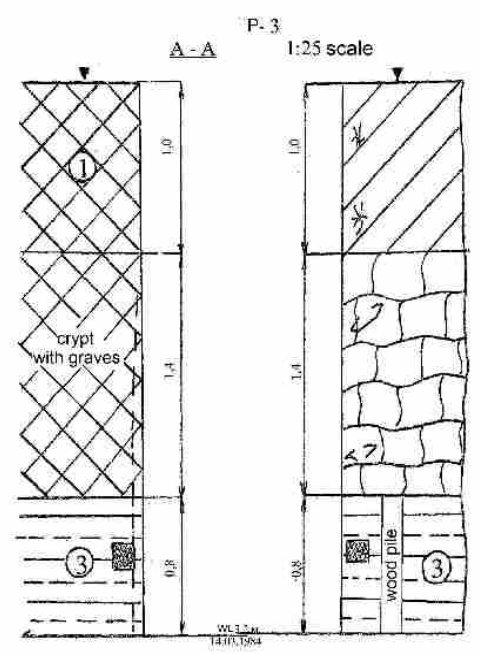

Fig.8. Section for the pits Nr.3 
Table 1. Consolidated engineering-geological with a table for normative and calculated indices of soil properties

\begin{tabular}{|c|c|c|c|c|c|c|c|c|c|c|c|c|c|c|c|c|c|c|}
\hline \multirow{4}{*}{$\stackrel{9}{1}$} & \multirow{4}{*}{ 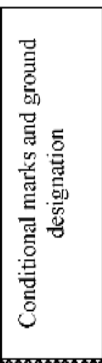 } & \multirow{4}{*}{$\begin{array}{l}\text { Soil name } \\
\text { (in accordance with SNiP-II-15-74) } \\
\text { GOST 25100) - } 82\end{array}$} & \multicolumn{8}{|c|}{ Normative values } & \multicolumn{6}{|c|}{ Calculated values } & \multicolumn{2}{|c|}{$\begin{array}{c}\text { Additional } \\
\text { information }\end{array}$} \\
\hline & & & 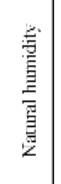 & 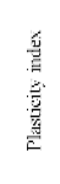 & $\begin{array}{l}\text { 鿓 } \\
\text { 营 } \\
\frac{\pi}{2}\end{array}$ & 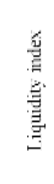 & 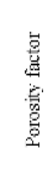 & 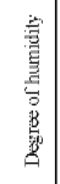 & 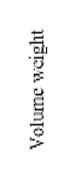 & 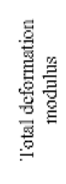 & \multicolumn{2}{|c|}{ 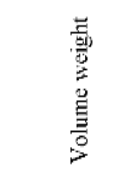 } & \multicolumn{2}{|c|}{ 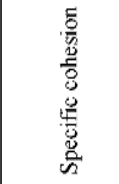 } & \multicolumn{2}{|c|}{ 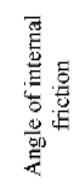 } & \multirow{2}{*}{ 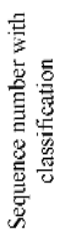 } & 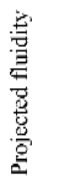 \\
\hline & & & W & $\mathrm{J}_{\mathrm{P}}$ & $\mathrm{W}_{\mathrm{P}}$ & $J_{\perp}$ & c & $\mathrm{G}$ & $\mathrm{x}$ & $\mathrm{E}$ & $\mathrm{XI}_{\mathrm{I}}$ & $Y_{\square}$ & $\mathrm{C}_{1}$ & $\mathrm{C}_{\mathrm{II}}$ & $\varphi_{\perp}$ & $\varphi_{1}$ & & $J_{\mathrm{L}}$ \\
\hline & & & & & Unitt & ntion & & & $\mathrm{recos}^{2}$ & krocich ${ }^{2}$ & gt & & kgficm & & dcegric & & & 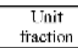 \\
\hline 1 & . & $\begin{array}{l}\text { Bulk ground - sandy loam, samd with plant } \\
\text { residues, and inclusion of solid construction } \\
\text { deltris it to } 30 \% \text { or the burial }\end{array}$ & & & & & & & & & & & & & & & $24 a$ & \\
\hline 2 & (2) & $\begin{array}{l}\text { Finc, quartz, densc sand with sandy loam } \\
\text { layers, wet yellow-gray dusty sand of } \\
\text { average size. }\end{array}$ & 0,13 & - & - & - & 0,55 & 0,64 & 1,93 & 360 & $\begin{array}{l}1,93 \\
\pm 0,04\end{array}$ & $\begin{array}{l}1,93 \\
\pm 0,03\end{array}$ & 0,03 & 0,04 & 33 & 36 & $27 \mathrm{n}$ & \\
\hline 3 & 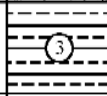 & $\begin{array}{l}\text { Sandy loam plastic with thin interlayers and } \\
\text { lenses of dark gray sand with admixture of } \\
\text { construction debris and household waste, } \\
\text { yellow-gray. }\end{array}$ & 0,22 & 0,03 & 0,21 & 0,46 & 0,80 & 0,73 & 1,01 & 120 & $\begin{array}{r}1,81 \\
\pm 0,11\end{array}$ & $\begin{array}{l}1,81 \\
\pm 0,06\end{array}$ & 0 & () & $\begin{array}{l}23 \\
\pm 0\end{array}$ & $\begin{array}{l}26 \\
\pm 3\end{array}$ & $34 \pi$ & $\because$ \\
\hline 4 & 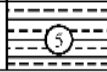 & $\begin{array}{l}\text { Sandy loam with an admixlure of plant } \\
\text { residues, constrnction waste, household } \\
\text { waslc, sand inlcrlaycrs, dark gray. }\end{array}$ & 0,23 & 0,05 & 0,24 & 0 & 0,99 & 0,59 & 1,64 & 60 & - & 1,64 & 0,05 & 0,07 & 17 & 19 & 346 & $\therefore 1$ \\
\hline
\end{tabular}

The table gives the values for normative and calculated indices of soil properties by monoliths selected from under the base of the church foundation above the groundwater level.

Table 2. Soil conditions construction site

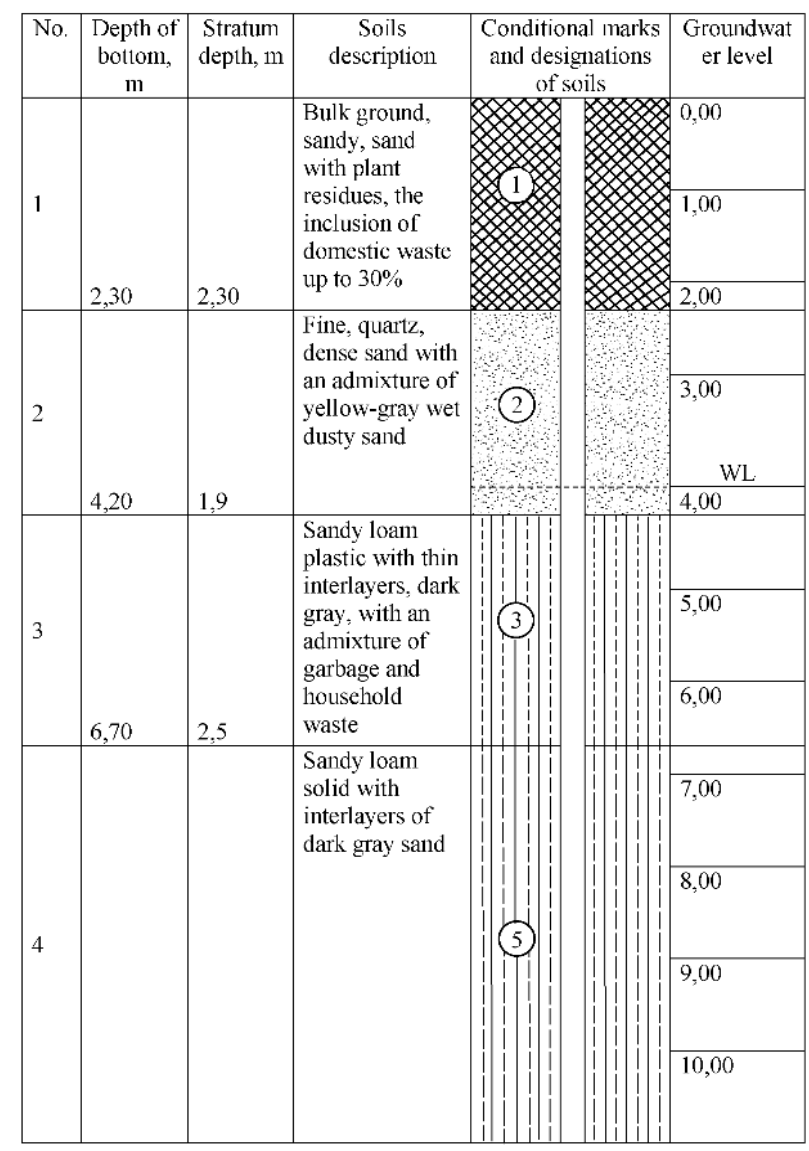

State scientific and technological center for the conservation and restoration of monuments conducted studies for building material of foundations and walls of the church to determine their composition, strength, salinity, moisture, and biological damage.

It was found that brick walls were made of yellow and dark red brick on lime-sand mortar with the lime to sand ratio 1:5. Brick has a fragile structure, and water absorption more than $19 \%$. The testing of the strength in compression rate showed the result of more than $25 \mathrm{~kg} / \mathrm{cm}^{2}$.

The main measures for the elimination of alert condition foresaw:

- strengthening damaged foundations and framework for establishing base-foundationbuilding equilibrium;

- developing measures to protect the base and foundation from underflooding;

- providing reliable vertical and horizontal waterproofing for the basement walls and floors, and for the entire underground part of the church;

- works on the antiseptic treatment for the surfaces affected by Micromycetes fungi complex and eliminating salinity from the brickwork and plaster of the walls;

- establishing a reliable geodetic control for the structure deformation [12-15]. 


\section{STRENGTHENING OF THE DESTROYED BASIS AND FOUNDATIONS OF THE $\mathrm{CHURCH}$}

When the project of monument restoration was considered, several options to strengthen the foundations and bases were discussed, including eyeliner foundation pillars to expand the sole foundation, strengthening the soil by injection, amplification using bored and pressed piles, placing a solid base plate [1619].

Analysis of the considered options showed that during strengthening the foundation pillars in wells, establishing outrigger bored and pressed piles under the existing foundations, uneven efforts will appear in structures that need to be carried out in sections, as the efforts cannot be passed to the basis. The disadvantages of the above options are also the strengthening, complexity, and laboriousness, the cost of these works within a construction site.

Comparing the technical and economic parameters, as well as the considered options, the most rational was the use of root piles (Figs. $9-15)$.

The main advantages of this method were the following:

- the possibility of arranging piles through existing structures reinforcing the foundations with the injection under pressure;

- the preservation of authentic exterior of the architectural monument;

- pressing the mortar in well with simultaneous resume of its pressure, which provided filling cracks in the construction of the foundation, compacted surrounding soil, provided roughness around piles surface, which increased their carrying capacity;

- settling of root piles due to their pressing usually no more than a few millimeters even for loads close to the threshold of the material strength;

- static equilibrium is not disturbed for existing foundations because of the arrangement of piles is performed using small-sized equipment with high speed without vibration transmitted to the foundation.

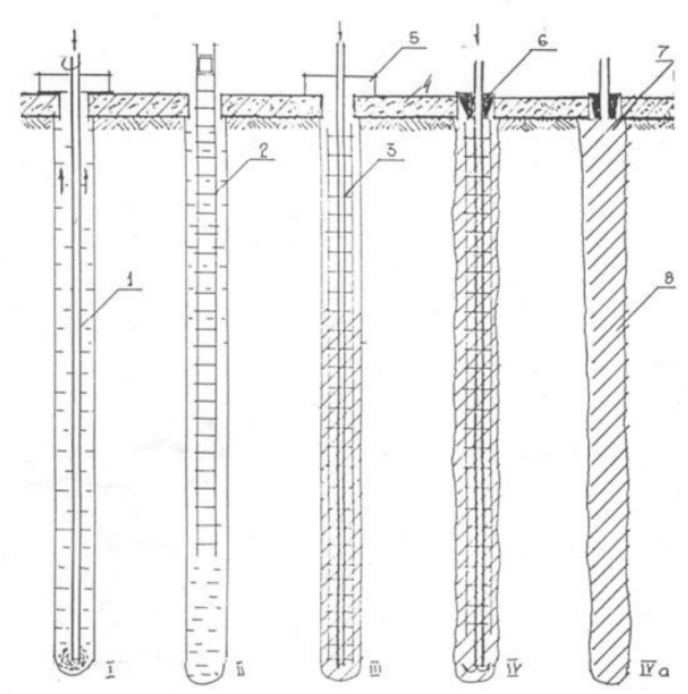

Technological scheme for arrangement of root piles with wells washing by concrete mortar: I boring with chisel drilling bits; II - installing reinforcement cages; III - installation of injection pipe and filling the hole with a mortar; IV - tampons and establishing pressing of wells; IVa pressing of wells at the mouth of the pile. 1 drilling pipe; 2 - reinforcing cage; 3 - injection pipe; 4 - reinforced foundation; 5 - mouth tray; 6 - swab with gland; 7 - extended part of the pile; 8 - finished pile.

Fig.9. Flowsheet of root piles use

The total number of root piles was 506 pcs., diameter $132 \mathrm{~mm}$, the length of the pile was $16 \mathrm{~m}$, the angle $15-19$ degrees.

The structure of the strengthening works also included cement injection under pressure to the foundations and rubble masonry. Arranging of piles was performed by SKB-4E cutting chisel (Fig.12). Drilling of masonry was conducted by blowing air and soil drilling with flushing by pre-cast concrete using hydrocyclone pumping unit УСГУ-2. Construction deformation was stopped after strengthening the monument of architecture.

\section{MEASURES FOR PROTECTION THE BASE AND FOUNDATION OF THE CHURCH FROM UNDERFLOODING}

Scientific and technological inspection [20] performed in 1998, was intended to establish the real picture of the moisture state for the church, identify the causes of soaking for the 


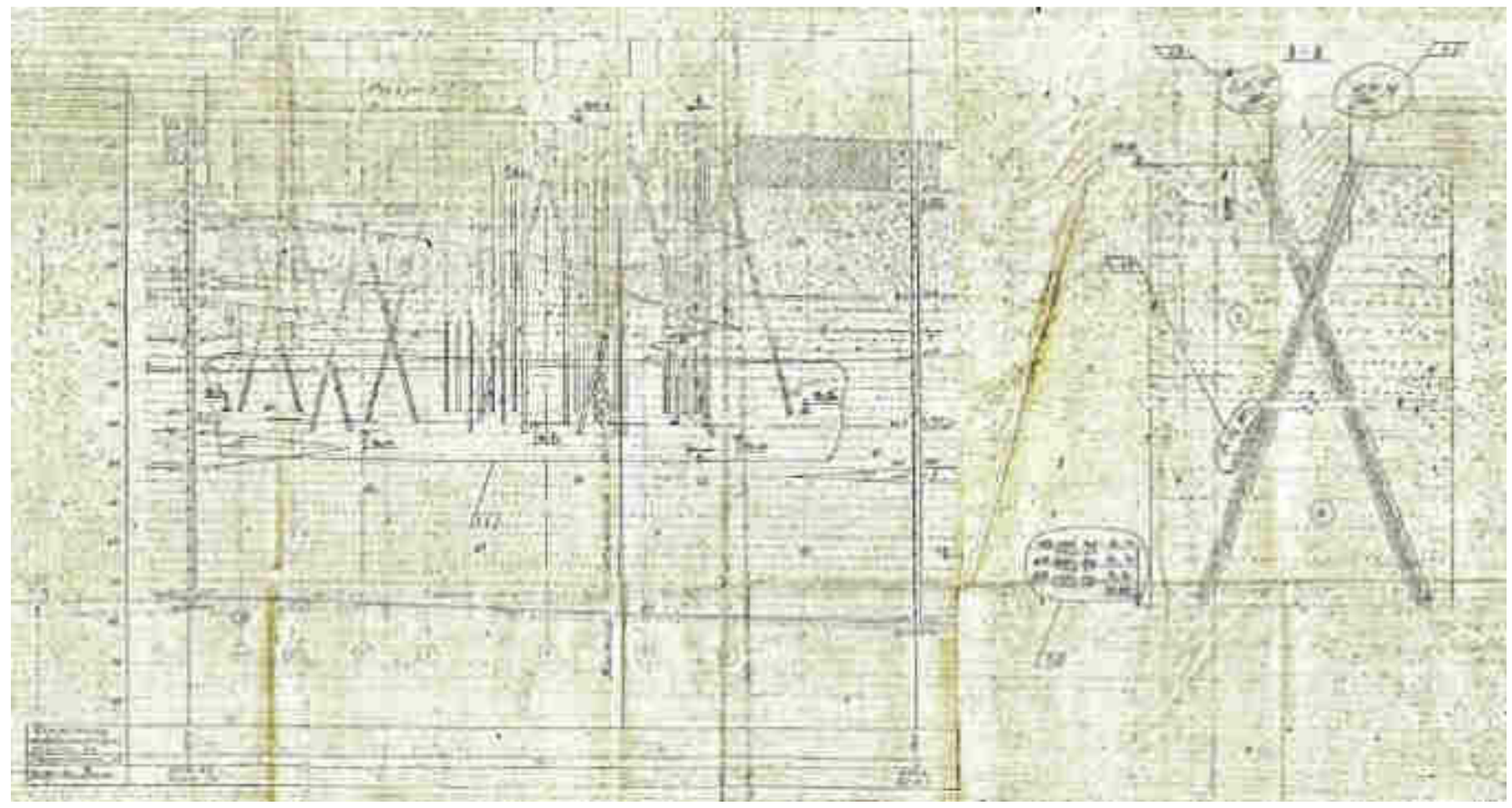

Fig.10. Scheme for putting building on the geological section

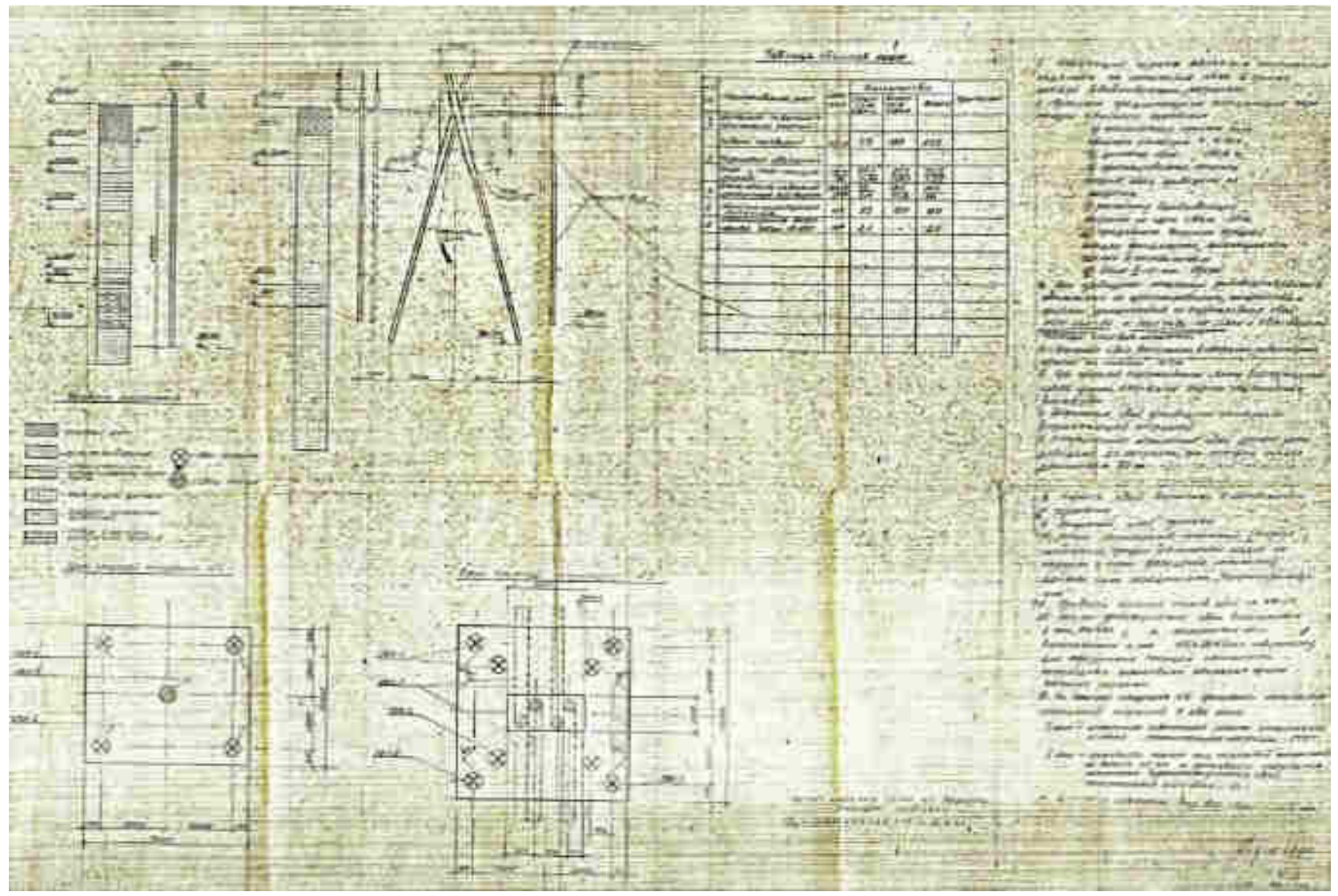

Fig.11. Test for the pile in the soil by axial load 
basement, and to develop technologies of waterproofing, as well as other repair and restoration works.

The samples of building materials were taken during the inspection to determine their composition, strength, salinity at the surface of the plaster and brickwork; measurements of moisture for the brickwork and air samples were conducted; the samples of biological damages were taken. Separately, an analysis of the water, which was in the basement, was conducted.

Basement moisture condition (Fig.16) was unsatisfactory, the basement was underflooded all the time and water was always there. The water level rose to a height of $40 . .50 \mathrm{~cm}$ from the floor and depended on changes in the level of groundwater. Moisture of the plaster exceed permissible limits, plaster was covered with efflorescence. In some places, there was peeling, breaking, and some heavy losses of laying bricks. In the north wall, bricks inrush amounted to $15 \mathrm{~cm}$, cracks in walls and arches reached up to $30 \mathrm{~mm}$.

Analysis of the moisture condition for the laying lower sections of the walls testified that the moisture for the walls was significantly

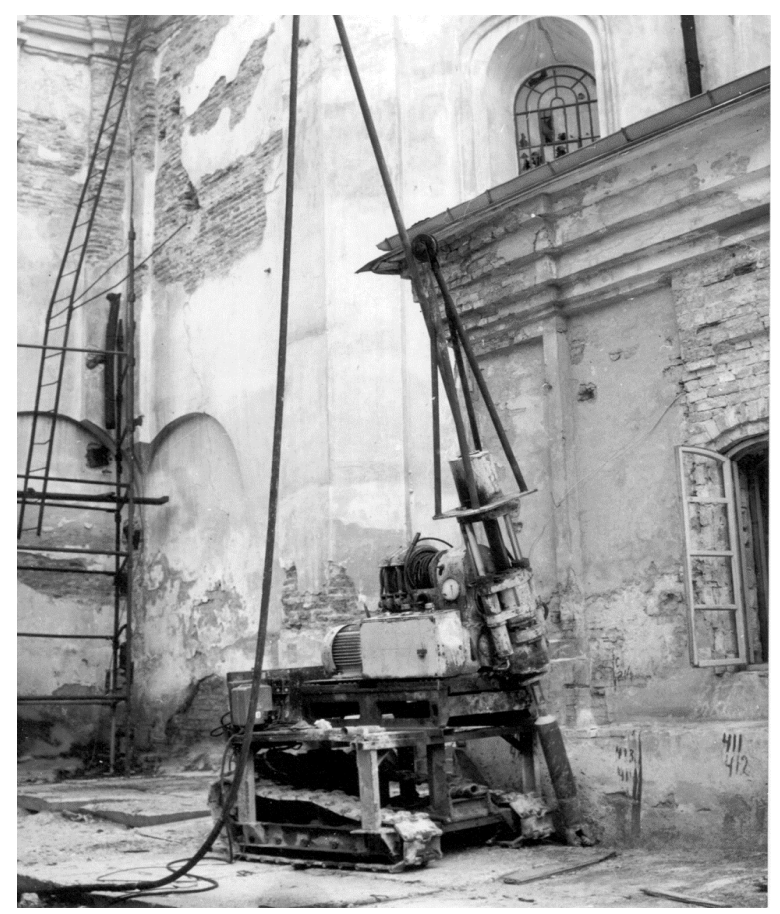

Fig.12. Drilling machine СКБ-4Е higher than the permissible limits and reached above $12 \ldots 14 \%$, resulting in lesions of building materials with Micromycetes fungi complex and caused the plaster and brickwork destruction. Moisture indicators in the interior walls of the church basement were lower and showed existing capillary suction of moisture.

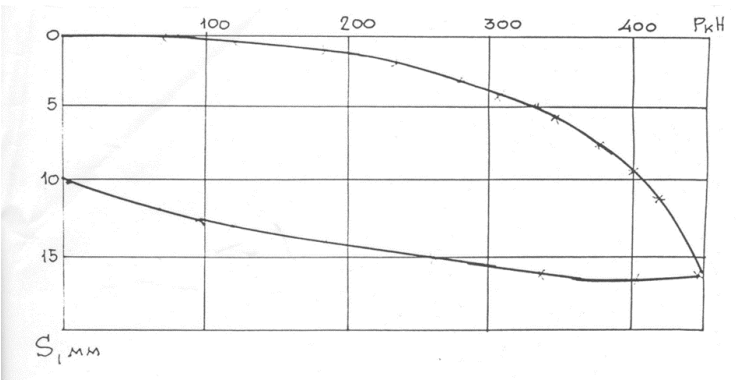

Fig.13. $S=f(P)$ plot for the studied root pile DP-1 at strengthening the foundations of the Mykola Pritisk's church in Kyiv

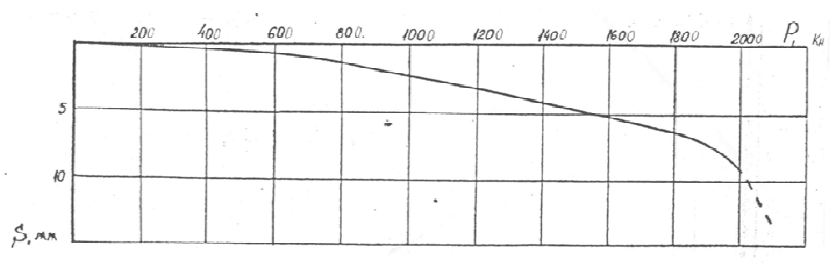

Fig.14. $S=f(P)$ plot for the studied cluster of four root piles, connected with DR-1 rostverk at strengthening the foundations of the Mykola Pritisk's church in Kyiv

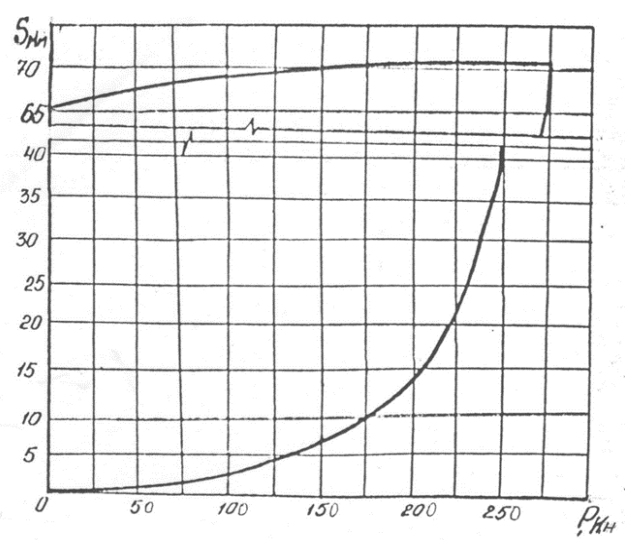

Fig.15. $S=f(P)$ plot for the studied root pile DP-1 on the break at strengthening the foundations of the Mykola Pritisk's church in Kyiv 


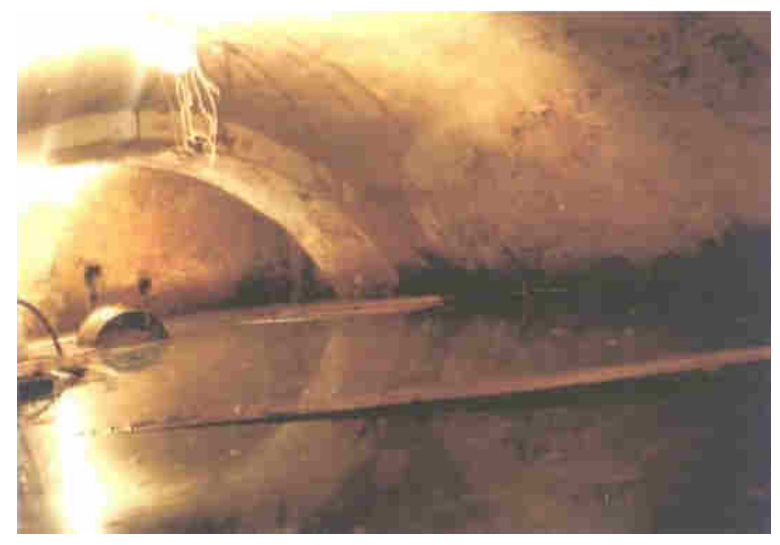

Fig. 16. Basement before the work

Conducted chemical analysis of water in the interior of the basement testified that the ground water source is wetting. This is consistent with the fact that the water level in the basement reduced in summer.

Increased groundwater level is typical for Podil and caused underflooding in many houses in this area.

Analysis of the water-soluble salts content in the walls of the church basement showed their significant availability and salts crystallization on the material surface. Over time, crystals grow in size, are beginning to put pressure on the building material, leading to its destruction.

Tests on the water absorption and strength for wall brick were performed, and the results of these studies for water absorption averaged more than $19 \%$, and the strength in compression $-25 \mathrm{~kg} / \mathrm{m}^{2}$.

Based on technological research of the church, it was concluded and the following recommendations were issued:

1. The main reason for the church basement becoming soaked is the high level of groundwater.

2. At a height of 1,5 meters from the floor, high moisture of the church walls is caused by capillary suction of ground water.

3. To normalize moisture and the state of the walls, and to prevent the ingress of water into the basement, vertical and horizontal waterproofing must be performed.

4. The church walls and basement are affected by Micromycetes fungi complex and require antiseptic treatment of surfaces.
5. Plaster salinity is very high and should be decreased.

6. It is urgent to perform landscaping, reconstruction of skirting for the drainage of surface rainwater from the church.

In order to develop a reliable, durable and cost-effective technology for waterproofing of the church walls, technological schemes of several companies were considered: the Dutch «Dry works», Spanish «Drizoro», German «Remmers» and «Deitermann».

These projects differ in cost, cost of materials, their durability and guarantees having the same technological schemes.

Due to the warranty over 10 years, the lowest cost of materials for complex work, and that the walls not only get a protection from moisture, but also are strengthened, the technology of German company «Remmers» was chosen.

Performing a full complex of works on drainage and protection for the walls from moisture was divided into three main stages:

1. Horizontal waterproofing and applying sanifying plaster for the walls in the church basement in the interior and on the façade;

2. Work on drainage and waterproofing for the basement walls and floors;

3. Repair of paving around the church.

The work was carried out using waterproof materials and sanifying plaster of the «Remmers» company according to the company technology.

1. Drainage for the moisture of the basement (Fig. 17).

The technology included the following steps:

- removing destroyed plaster;

- destructive laying disassembly;

- surface dedusting;

- replacing for the lost bricks with the new;

- crack injection with the mortar;

- bricklaying mortar restoration and joints filling with AISIT Grundputz;

- dust cleaning for the holes;

- filling holes by $2-3$ injection with AIDA KEISOL;

- two antifungal treatments for the walls;

- holes treatment with AIDA Borlochsuspension; 


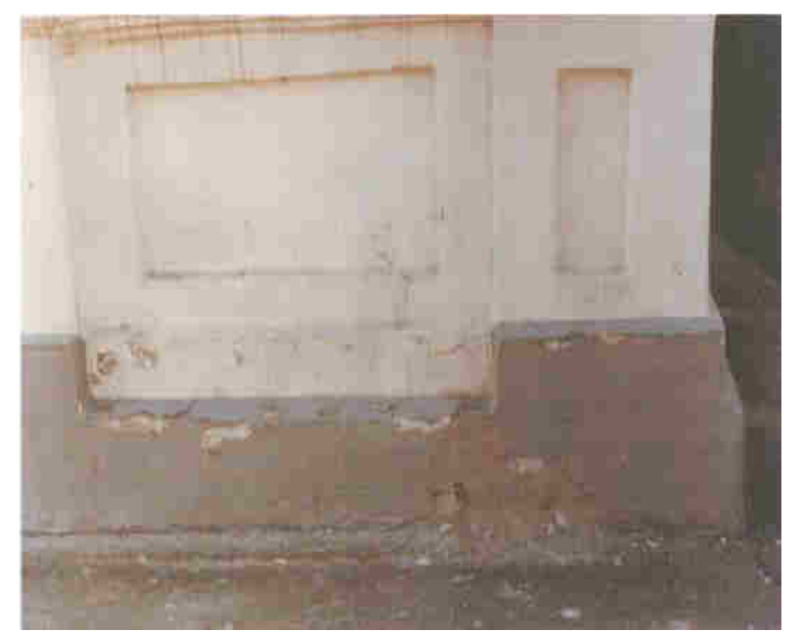

Fig.17. Basement before the work

- applying preparatory plaster AISIT Special-Vorsspritzmortel; al;

- applying plaster AISIT Sanierputz Spezi-

- plaster smoothing;

- leveling with AISIT Grundputz coating;

Horizontal waterproofing.

2. Drainage of walls and vaults of the basement moisture.

Arrangement of horizontal and vertical waterproofing.

Walls and vaults:

- pumping water out of the basement;

- removal of plaster;

- removal of debris;

- destructive laying disassembly;

- room dedusting;

- replacing for the lost bricks with the new;

- crack injection with the mortar;

- drilling holes with a diameter of $30 \mathrm{~mm}$;

- dust cleaning for the holes;

- filling holes by $2-3$ injections of AIDA KEISOL;

- two antifungal treatment for the walls;

- holes treatment with AIDA Borlochsuspension;

- applying preparatory plaster

- AISIT Special-Vorsspritzmortel;

- strengthening and alignment of brickwork and joint filling with AISIT Grundputz;

- protection against moisture by applying a slurry saltproof

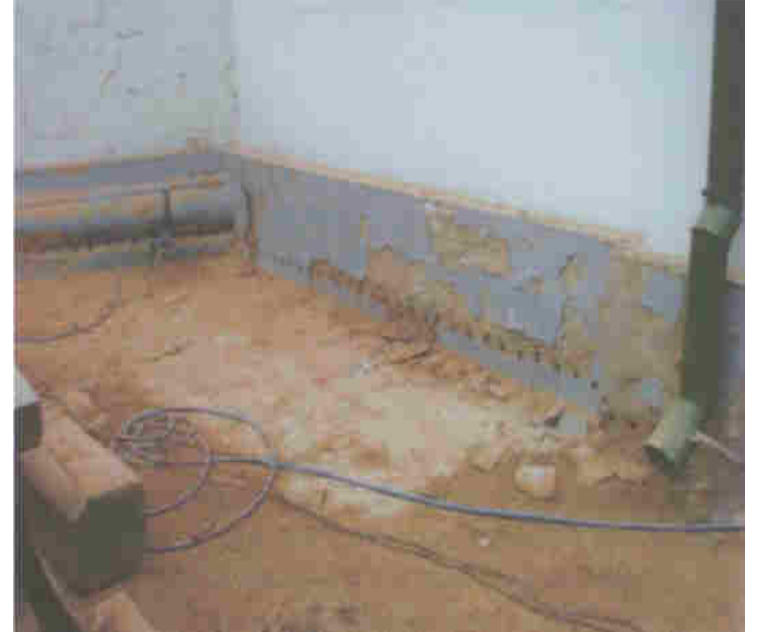

Fig.18. Drilling holes in the basement facade

AIDA Sulfatexschlamme;

- applying preparatory plaster layer on the entire surface of the wall;

- applying plaster base layer;

- plaster grinding;

- painting walls.

Drilling of holes was performed according to the technology (Figs.18-22).
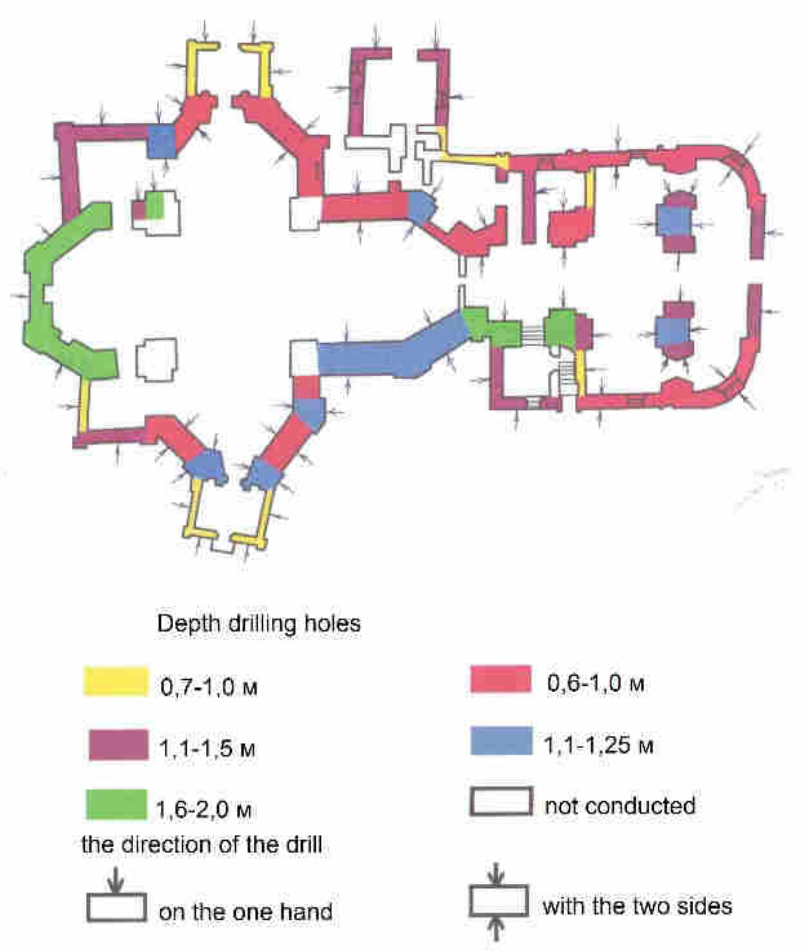

Fig.19. Layout for the holes drilling 


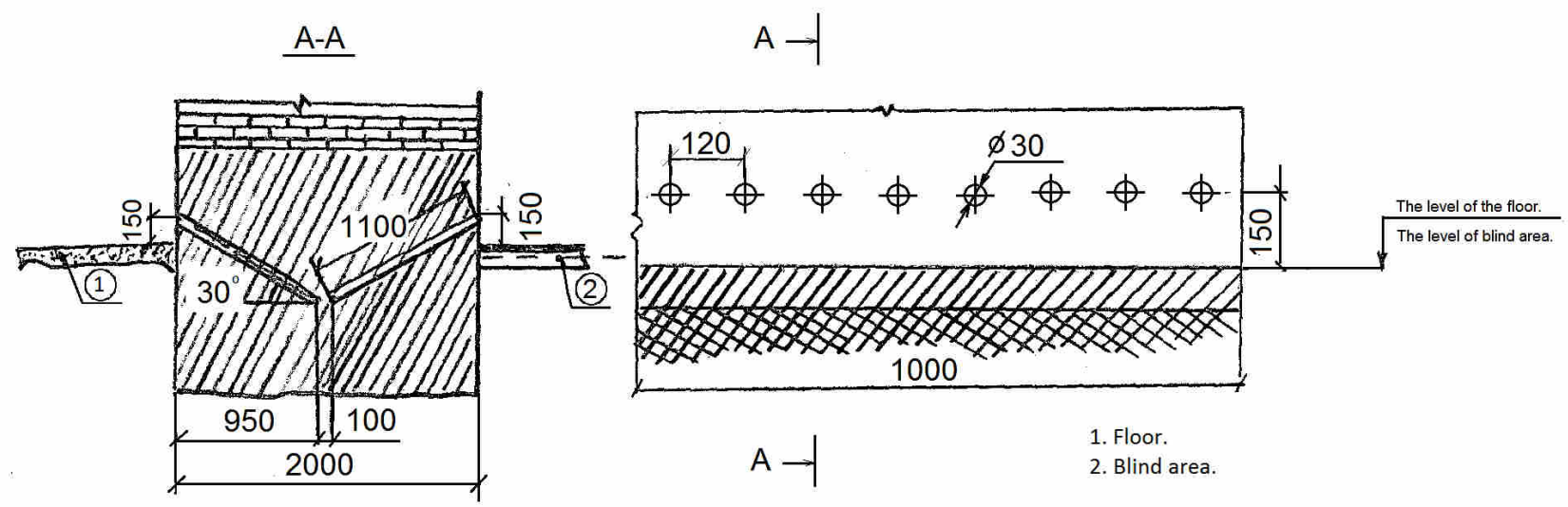

Fig.20. Layout for the holes

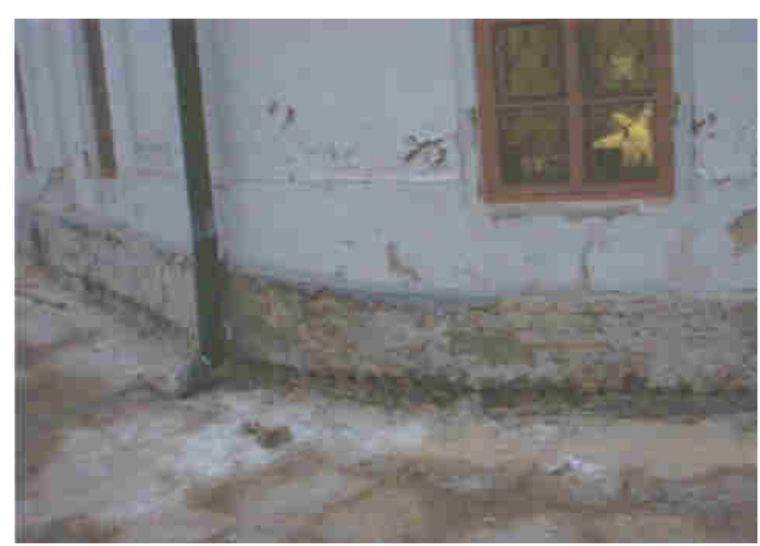

Fig.21. Drilling holes in the basement facade

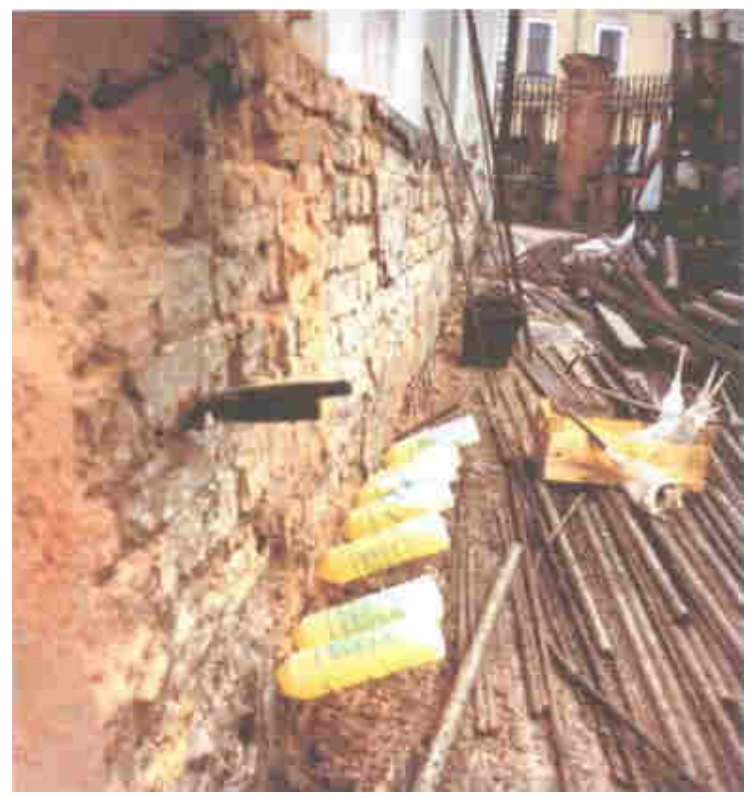

Fig.22. Fill in drilled holes with Aida KIESOL solution
Holes were drilled in the walls around the perimeter of the church outside the basement (see Fig.19), in places, where the wall thickness is more than $2 \mathrm{~m}-$ on both sides. At the altar, the drilling was performed only from outside. The depth of the holes and their location are shown at the layout (see. diagrams at the sheets).

After drilling holes, the dust removal was performed.

After the full technological cycle of vertical and horizontal waterproofing arrangement, the moisture of the church walls, both outside and inside, become normal (Fig.23).

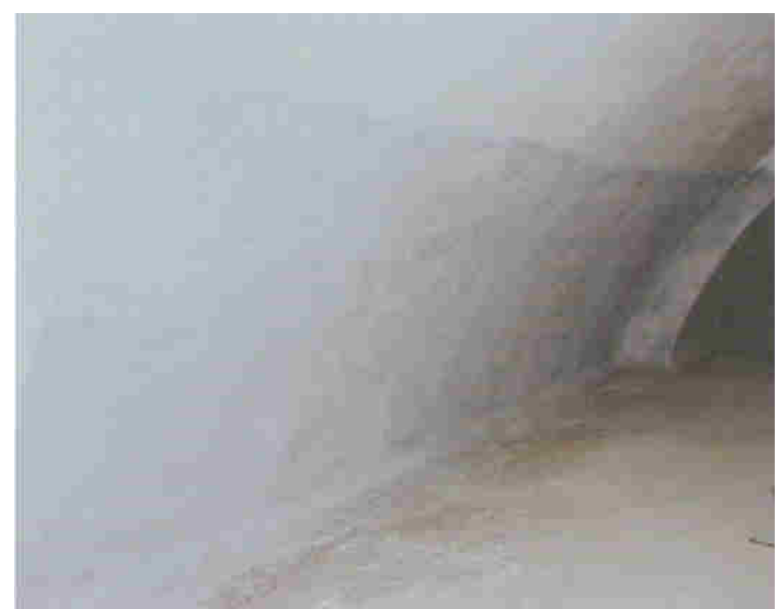

Fig.23. Basement after the work 


\section{CONCLUSIONS}

1. Architecture monuments, which are in the state register and protected by the state according to the Art. 54 of the Constitution of Ukraine and the Law of Ukraine "On Protection of Cultural Heritage of 08.06.2000. № 1805-III, should be monitored for their correct operation.

2 . For the early detection of monument degradation, it is necessary to provide geodetic deformation monitoring for the buildings, as well as for the changes in the hydrogeological conditions of the monument location.

3 . To take timely measures to drain surface water and protect the base and foundation of the monument from the raising level of groundwater.

4. Do not agree new construction projects in the protected area of the architectural monuments, which can lead to underflooding and increasing groundwater level.

\section{REFERENCES}

1. Mykola Orlenko, 1996. 50 rokiv korporacii' Ukrrestavracija. Derzhavnyj komitet Ukrai'ny u spravah mistobuduvannja i arhitektury. Kyi'v-L'viv, Ukrrestavracija, 22 (in Ukrainian).

2. Mykola Orlenko, 2001. Korporacija Ukrrestavracija. Na mezhi tysjacholit'. At the turn of millenniums. Kyi'v, Ukrrestavracija, 156 (in Ukrainian).

3. Mykola Orlenko, 2002. Myhajlivs'kyj Zolotoverhyj monastyr. Metodychni zasady i hronologija vidtvorennja. Kyiv, Gopak, 160 (in Ukrainian).

4. Mykola Orlenko, 2015. SvjatoVolodymyrs'kyj sobor v Hersonesi. Metodychni zasady i hronologija vidtvorennja. Kyiv, Feniks, 320 (in Ukrainian).

5. Mykola Orlenko, 2015. Uspens'kyj sobor Kyjevo-Pechers'koi' Lavry. Metodychni zasady i hronologija vidtvorennja. Kyiv Feniks, 832 (in Ukrainian).

6. DBN V.3.2-1-2004 Rekonstrukciya, remont, restavraciya ob'yektiv nevyrobny'choyi sfery 2005. Restavracijni, konservacijni ta remontni roboty na pam'yatkax kul turnoyi spadshhyny. Kyiv, Minrehionbud, 118 (in Ukrainian).

7. http://zakon2.rada.gov.ua/laws/show/1805$\underline{14}$, 13.06.2017.
8. Mykola D'omin ta in. 1997. Arhitekturna spadshhyna Ukrai'ny. Nr.4. Kyiv, Ukrai'noznavstvo, 208 (in Ukrainian).

9. Prysjazhnjuk V.F., 1999. Mistobuduvannja zakonodavchi akty. Kyi'v, Derzhbud Ukrai'ny, Ukrrahbudinform, 412 (in Ukrainian).

10. Serdjuk O.M., ta in., 2011. Zbirnyk normatyvno-pravovyh aktiv sfery ohorony kul'turnoi' spadshhyny. Ministerstvo kul'tury Ukrai'ny. Chernigiv, Naukovo-doslidnyj instytut pam'jatko ohoronnyh doslidzhen', 796 (in Ukrainian).

11. Otchet ob inzhenernyih izyiskaniyah dlya restavratsii Nikolsko-Pritiskoy tserkvi pamyatnika arhitekturyi XVII v. v g. Kieve, 1984. Ukrainskiy gosudarstvennyiy golovnoy institut inzhinerno-tehnologicheskih izyiskaniy (UKR GIINTIZ) Arhivnyiy Nr.5/216, 20 str. Fond nauchno-proektnoy dokumentatsii Kyivskogo nauchno-metodicheskogo tsentra po ohrane, restavratsii, prisposobleniyu pamyatnikov istorii i kultury. Kyiv, Gosstroy (in Russian).

12. Kateryna Pushkarova, Maryna Sukhanevych, Kateryna Bondar, 2015. The principles of composite construction penetrability waterproofing mortars with increased service life. Underwater Technologies, Vol.02, 46-52.

13. Nellya Leshchenko, 2016. Pre-project research cycle of the architectural environment of the small town's historical center as an analytical stage of it reconstruction. Underwater Technologies, Vol.03, 66-74.

14. Denys Khokhlin, 2017. Building protection in conditions of simultaneous availability of soil base substantial differential settlements and seismic hazard origins. Underwater Technologies, Vol.05, 54-60.

15. Victor Gaidaychuk, Konstantin Kotenko, Ivan Tkachenko, 2017. Integrated monitoring the technical condition of large-scale building structure. Underwater Technologies, Vol.05, 61-66.

16. Mykola Orlenko, 1989. Pidsylennia fundamentiv pamiatok arkhitektury za dopomohoiu buro-iniektsiinykh pal. Kyiv, Ukrrestavratsiia, Nr.8, 16-19 (in Ukrainian).

17. Mykola Orlenko ta in. 1996. Konservatsiia i restavratsiia pamiatok arkhitektury. Kyi'vL'viv, Ukrrestavratsija, 585 (in Russian).

18. Mykola Orlenko ta in., 2008. Inzhenerna pidgotovka vyrobnyctva. Kyiv, Ukrrestavracija, 96 (in Ukrainian). 
19. Ivan Mogytych, 1993. Visnyk chyslo 1. L'viv, Ukrzahidproektrestavracija, 82 (in Ukrainian).

20. Ustimenko O.B., ta in., 1999. Zvit pro vykonannia kompleksu robit po osushenniu ta hidroizoliatsii stin tsokolnoi chastyny pamiatky arkhitektury XVII st. tserkvy Mykoly-Pritiski vul. Khoreva 5 v m. Kyievi, Arkhivnyi Nr.8/101. Fond naukovo-proektnoi dokumentatsii Kyivskoho naukovo-metodychnoho tsentru po okhoroni, restavratsii ta prystosuvanniu pamiatok istorii kultury i zapovidnykh terytorii. Derzhavnyi naukovo-tekhnolohichnyi tsentr konservatsii i restavratsii pamiatok (DNTTs Konrest). Kyiv, 13 (in Ukrainian).

\section{Причины разрушения достопримеча- тельностей архитектуры и градостроения и способы усиления несущей способности основ и фундаментов}

\section{Николай Орленко}

Аннотация Основной проблемой аварийного состояния достопримечательностей является неудовлетворительное состояние основ и фундаментов, часто в результате их увлажнения. Неравномерные просадки фундаментов приводят к перераспределению усилий в несущих конструкциях и нарушению статики системы основа-фундамент-соружение. Поэтому любые реставрационные мероприятия начинают с ликвидации их аварийного состояния.
На примере церкви Николая Притиски на Подоле, где подтопление грунтовыми водами повлекло обвал юго-восточной части сооружения, описан порядок реставрационных работ на достопримечательности, которые начались с усиления разрушенных фундаментов и основы для возобновления статики системы основа-фундамент-сооружение, мероприятий по защите основы и фундаментов от подтопления, с обеспечением надежной вертикальной и горизонтальной гидроизоляции стен и полов подвала и всей подземной части церкви и работ по антисептической обработке поверхностей биопораженных и засоленных стен и штукатурки. После этого обеспечивалась организация надежного геодезического контроля за деформацией сооружения.

Ключевые слова: основания и фундаменты, грунтовые воды, усиление. 